\title{
Community Literacies: Research and Practice
}

\author{
NICOLA FRIEDRICH \\ Ontario Institute for Studies in Education/University of Toronto
}

\author{
CAROL DOYLE-JONES \\ Niagara University
}

In May 2015, a group of language and literacy researchers gathered at the University of Ottawa for the $12^{\text {th }}$ Annual Language and Literacy Researchers of Canada (LLRC) Pre-Conference. The focus of the conference was Community Literacies: Research and Practice. In keeping with tradition, language and literacy scholars at varying stages of their academic careers engaged in exquisite conversations during which they shared their ideas for research projects, discussed the findings of research they had just completed, or provided constructive feedback in order to assist others in moving their research forward. Following the conference, we invited participants to submit manuscripts resulting from these conversations. As the final step of the process, we have created a special issue to highlight five manuscripts that we believe reflect the spirit of the LLRC Pre-conference and demonstrate the breadth and depth of research in the field of language and literacy education in Canada.

In selecting the first two papers of this special issue, we highlight research that seeks to expand our understanding of the role played by adults in young children's literacy and language learning. In her paper, To digital or not to digital: How mothers are navigating the digital world with their young children, Laura Teichert examined digital literacy practices in the homes of three middle-class, English speaking families in order to unpack the various tensions mothers experience around their young children's participation in these practices. Laura chose an ethnographic case study design set within the sociocultural theory of learning (Vygotsky, 1978). Drawing from her semi-structured interviews with the three mothers, Laura first presents the reader with snapshots of digital literacy practices within each of the homes and then discusses how the mothers came to perceive these practices as being problematic.

Xiaoxiao Du chose as her focus the pedagogical practices of teachers that support young Chinese children's heritage language learning in a community heritage language school. Similar to Laura, Xiaoxiao chose a case study design and drew from tenets within the socio-cultural perspective of literacy (Jewitt \& Kress, 2003; New London Group, 1996; Wertsch, 1994). By observing literacy events within the classroom through a multimodal lens, her paper, Rethink about heritage language learning: A case study of children's Mandarin Chinese learning at a community language school in Ontario, Canada, she provides detailed descriptions of the teachers' pedagogical practices and the children's learning within a first grade classroom. Xiaoxiao's findings challenge the prevailing view that children learn Chinese through repeated literacy activities and provide support for heritage language teachers exploring creative pedagogical practices within the classroom.

With the selection of the remaining three articles, we shift the focus of the special issue from literacy practices that support young children's language and literacy 
development to educational practices that understand students and families as active participants in the educational process. In her paper, "I am no Othello. I am a lie": A consideration of reader-response theory as language learning pedagogy and teacher philosophy, Heba Elsherief presents a case study of a language student's responses within an independent study to support her argument for understanding transactional/reader response theory as both teaching philosophy and pedagogy. By juxtaposing the student's responses to the text, Season of Migration to the North (Salih, 2009), Heba effectively captures reader response as an interpretive act, one that prioritizes the language student's ability for meaning-making, rather than a lesson plan idea.

In the paper, Family-school (dis)engagement: Understanding what it is, what it's not, and what to do about it, Michelann Parr and Marianne Vander Dussan describe the interplay between families and schools through collaborative inquiry (Riel, 2010) and community-based research (Strand, Marullo, Cutforth, Stoecker, \& Donohue, 2003). Focusing on family-school engagement practices (McKenna \& Millen, 2013), the authors share their own experiences in the field and highlight key questions generated by the inquiry teams. By shifting the family-school teams to listening, sharing, and asking, Michelann and Marianne suggest evidence-based strategies to support a form of familyschool engagement that repositions both parties as equal partners in children's education.

Karen Krasny and Sonya Sachar provide the reader with an historical review of Canadian language and multicultural policy in order to demonstrate how these policies shape educational practice. In their paper, Legitimizing linguistic diversity: The promise of plurilingualism in Canadian schools, the authors explore the term pluralingualism (Canagarajah \& Liynage, 2012; Coste, Moore, \& Zarate, 2009; Piccardo, 2013). They argue for educators adopting a plurilingual orientation to language education in the classroom, one in which students are understood as being social actors who use multiple languages during intercultural interactions. Karen and Sonya provide support for their argument by positioning themselves as social actors and sharing their own experiences with using language for specific purposes in two different contexts.

The authors in this special edition have interwoven strong threads of practices that together share stories of languages and literacies in our communities. From digital literacy to language practices, to cultural interactions and engagement practices, how the researchers and participants understand pedagogy as meaning-making is at the core of these papers. We are pleased to share these important papers with you and look forward to continuing our exquisite conversations.

\section{Acknowledgements}

We would like to thank all our pre-conference participants and reviewers for their expertise and feedback.

\section{References}

Canagarajah, S., \& Liynage, I. (2012). Lessons from pre-colonial multilingualism. In M. Martin-Jones, A. Blackledge, \& A. Creese (Eds.), The Routledge handbook of multilingualism (pp. 49-65). London, England: Routledge.

Coste, D., Moore, D., \& Zarate, G. (2009). Plurilingual and pluricultural competence. (original French version 1997). Studies towards a Common European Framework of Reference for language learning and teaching. Strasbourg: Council of Europe. 
Retrieved from:

http://www.coe.int/t/dg4/linguistic/Source/SourcePublications/CompetencePlurili ngue 09 web en.pdf

Jewitt, C., \& Kress G. (Eds.) (2003). Multimodal Literacy. New York, NY: Peter Lang Publishing Inc.

McKenna, M. K., \& Millen, J. (2013). Look! Listen! Learn! Parent narratives and grounded theory models of parent voice, presence, and engagement in K-12 education. School Community Journal, 23(1), 9-48.

New London Group. (1996). A pedagogy of multiliteracies: Designing social futures. Harvard Educational Review, 66(1), 60-92.

Piccardo, E. (2013). Plurilingualism and curriculum design: Toward a synergic vision. TESOL Quarterly, 47(3), 600-614.

Riel, M. (2010). Understanding action research. Retrieved July 2013, from http://cadres.pepperdine.edu/ccar/define.html

Salih, T. (2009). Season of migration to the north. New York, NY: New York Review of Books

Strand, K., Marullo, S., Cutforth, N., Stoecker, R., \& Donohue, P. (Eds.). (2003). Community-based research and higher education: Principles and practice. San Francisco: Jossey-Bass Publishers.

Wertsch, J. V. (1994). The primacy of mediated action in sociocultural studies. Mind, Culture and Activity, 1(4), 202-208

Vygotsky, L. (1978). Mind in Society: The development of higher psychological processes. Cambridge, MA: Harvard University Press. 